\title{
Increasing the Onion Yield by the Arrangement of Growing Space and Organic Fertilizer
}

\author{
Luh Kartini $^{1}$, Made Sri Yuliartini ${ }^{2}$, Anak Agung Ngurah Mayun Wirajaya ${ }^{3}$ \\ \{luhkartini@gmail.com ${ }^{1}$, yuliartinisri@yahoo.co.id ${ }^{2}$, mawir61@yahoo.com 3 \} \\ Program Studi Agroteknologi Fakultas Pertanian Warmadewa Denpasar-Bali, \\ Indonesia ${ }^{123}$
}

\begin{abstract}
Then aims of this research is for getting the right growth space and optimal concentration of D.I Grow fertilizer so that the maximum growth and yield of onion can be obtained. This research has been carried out in Angseri Village, Baturiti District, Tabanan Regency, Bali Province. This experiment used a randomized block design with a factorial pattern consisting of 2 factors, namely the arrangement of growing space and the concentration of Diamond Interest (D.I.) fertilizer which consisted of 4 levels each. The interaction between the growing space and the concentration of D.I.Grow fertilizer had no significant effect $(\mathrm{P} \geq 0.05)$ on all observed variables. The arrangement of growing space has a very real $(\mathrm{P}<0.01)$ effect on maximum plant height, maximum leaf number and number of tubers per clump; has significant effect $(\mathrm{P}<0.05)$ on the fresh weight and dry weight of tuber oven per clump as well as fresh weight and dry weight of stover oven per clump and no significant effect $(\mathrm{P} \geq 0.05)$ on the harvest index. The treatment of D.I. Grow fertilizer concentration significantly effected $(\mathrm{P}<0.05)$ to the maximum plant height and fresh weight and dry weight of stover, and had a very real $(\mathrm{P}<0.01)$ effect on the maximum number of leaves and the number of tubers per clump. However, the effect is not real $(\mathrm{P}>0.05)$ on the fresh weight and dry weight of the tuber oven per clump and harvest index. The highest fresh weight and oven dry weight of tuber per clump was obtained in the setting of the growing space of $20 \mathrm{~cm} \times 20 \mathrm{~cm}$, namely $44.17 \mathrm{~g}$ and 4.52 $\mathrm{g}$ increased by $18.92 \%$ and $88.33 \%$ compared to the lowest yield in the arrangement of space growing $20 \mathrm{~cm} \times 10 \mathrm{~cm}$ is $37.14 \mathrm{~g}$ and $2.40 \mathrm{~g}$. The increasing amount of fertillizer concentration of DI Grow caused the increasing of the growth and yield of onion. The highest number of tubers per clump was at $7,5 \mathrm{ml}^{1} \mathrm{l}^{-1}$ of DI Grow fertilizer concentration, which was 8.11 tubers, which increased by $22.87 \%$ which was not significantly different at the concentration of DI Grow fertilizer $7,5 \mathrm{ml} . \mathrm{l}^{-1}$ which was 18.02 tubers increasing by $21.52 \%$ compared with a concentration of fertilizer D I Grow $0 \mathrm{ml} \mathrm{l}-1$ wich is 6,60 ubers.
\end{abstract}

Keywords: The arrangement of growing space, D.I.Grow fertilizer and onions plant

\section{Introduction}

Red onion plants are horticultural plants that are increasingly gaining attention both from the community and the government. Over the past few years, shallots include six major commodities of vegetables exported together with cabbage, blunkol (cabbage flowers), chili, tomatoes, and potatoes. Even this shallot is not only exported in the form of fresh vegetables, 
but also after it is processed into fried onion products [1]. Shallot is a spice vegetable that, although not native to Indonesia, but its use as a delicious spice in cuisine is closely related to the tongue of the Indonesian people. Almost all Indonesian dishes use onion as one of the flavorings [2].

Onions contain red nutrients that are sufficiently complete every 100 grams Shallot contains Carbohydrates $9.34 \mathrm{~g}$; sugar $4.24 \mathrm{~g}$; fat $0.1 \mathrm{~g}$ protein $1.1 \mathrm{~g}$; air $89.11 \mathrm{~g}$ and vitamin C $7.4 \mathrm{mg}(12 \%)$ [3]. Shallots have properties as traditional medicine such as treatment: fever in children, flatulence, vomiting, colds, scrapings, coughing, dysentery, hypertension, diabetes, air lice, boils / sores, swollen breasts / mastitis, airborne in children hereditary fever, canker sores [4].

The center for producing shallots in Bali is in Songan Village, Kintamani, Bangli Regency, although the quality is still inferior to imported products. Besides in Songan Village, Bangli Regency is still scattered in several Regencies such as in Karangasem, Buleleng, Klungkung and a little in Jembrana whereas in Tabanan it is still not [5]. Red onion production in Bali in 5 years (2011-2015) experienced ups and downs every year, in 2011 the production of shallots reached 9,319 tons while in the following year 2012 and 2013 experienced a drastic decline of 8,666 tons and 7,977 tons while in 2014 increased to 11,884 tons and declined again in 2015 which reached 9,352 tons [6]. It can be said that the productivity of shallots in Bali is still low, while the need for shallots continues to increase, so it is necessary to optimize the cultivation of shallots in order to increase the production of shallots Deep plant concentration.

The highest number of tubers per clump was obtained at the DIGrow fertilizer concentration of $7.5 \mathrm{ml}$. 1-1 which was 8.11 bulbs which increased by $22.87 \%$ which differed significantly not the concentration of DI GOW fertilizer $5.0 \mathrm{ml}$. 1-1 ie 8.02 tubers increased by $21.52 \%$ compared to the DI Grow concentration of 0 ml.1-1 which was 6.60 tubers. The high number of tubers per clump is followed by the maximum plant height and maximum number of leaves. This is caused by the absence of $(\mathrm{N}, \mathrm{P}, \mathrm{K})$ available in fertilizer D.I. Grow supports which are not in the soil. From the results of soil analysis showed that the soil in the soil is very large than potassium through fertilizer D.I. Growing in plants will affect the number of tubers to increase. Potassium nutrients have a very important role in the placement and storage of assimilates, increasing the number of tubers [3].

The highest fresh weight and oven dry weight of tubers per clump were obtained in the treatment of DI Grow fertilizer $7.5 \mathrm{ml}$. $1-1$ of $42.78 \mathrm{~g}$ and $4.37 \mathrm{~g}$ increased by $9.02 \%$ and $47.13 \%$ compared to D I Grow treatment $0 \mathrm{ml} .1-1$ is $39.24 \mathrm{~g}$ and $2.97 \mathrm{~g}$ although it is not significantly different. The high oven dry weight of tubers per clump was followed by the maximum plant height, maximum number of leaves, number of tubers per clump, fresh weight and dry weight of stover oven. This is due to the higher concentration of fertilizer D I.Grow, the amount of nutrients available will meet the needs of plants so that it will produce high dry weight of plants. To carry out photosynthesis plants need nutrients, the more nutrients are absorbed, the greater the accumulative photosynthesis from photosynthesis, the greater the fresh weight of the plant. The dry weight of plants is a balance between taking carbon dioxide (photosynthesis) and expenditure (respiration), if respiration is greater than photosynthesis, the plant will reduce its dry weight and vice versa [7]. The dry weight of plants reflects the nutritional status of plants and plant dry weight is an indicator that determines whether or not a plant is very closely related to nutrient availability and absorption [8]. 


\section{Methodology}

\subsection{The Place and Time}

This research was carried out in paddy fields located in Angseri Subak, Angseri village, Baturiti District, Tabanan Regency. Demographically, Angseri vllageis located on a plateau with an altitude of +640 meters above sea level (asl), with topography including terracing land. This research was conducted from April to September 2018.

$$
\begin{aligned}
& \mathrm{J}_{2}=20 \mathrm{~cm} \times 15 \mathrm{~cm} \\
& \mathrm{~J}_{3}=20 \mathrm{~cm} \times 20 \mathrm{~cm} \\
& \mathrm{~J}_{4}=20 \mathrm{~cm} \times 25 \mathrm{~cm}
\end{aligned}
$$

The second factor is the concentration of fertilizer IN Grow $(\mathrm{G})$ which consists of 4 levels, namely:

$$
\begin{aligned}
\mathrm{G} 0 & =0 \mathrm{ml} .1-1 \\
\mathrm{G} 1 & =2.5 \mathrm{ml} .1-1 \\
\mathrm{G} 2 & =5.0 \mathrm{ml} .1-1 \\
\mathrm{G} 3 & =7.5 \mathrm{ml} .1-1
\end{aligned}
$$

The combination treatment was repeated 3 times, so 48 trial plots were needed.

\subsection{The implementation of the research}

The implementation of the research includes followed by:

1. Land preparation, the land in the tractor is then cleaned and leveled, plots made with a size of $1.5 \times 1.5 \mathrm{~m}$ with a mound of $20 \mathrm{~cm}$, distance between plots $30 \mathrm{~cm}$ and between replications $50 \mathrm{~cm}$, then 48 plots of experiment are covered with plastic mulch black silver.

2. Selection of seeds, red onion seeds used in this study are local seeds. The selected seeds are treated homogeneously or similar, namely from the weight of the tuber 5 grams per tuber, the tip of the tuber tubers cut $1 / 2$, and the seeds used have been stored 2 months after harvest. For the needs of the seed, $11 \mathrm{~kg}$ of shallot seedlings are needed.

3. Planting; Planting is done by making a planting hole on the surface of the mulch as deep as $3 \mathrm{~cm}$ with a spacing according to the treatment. Each planting hole is filled with one to two red onion bulbs weighing $5 \mathrm{~g}$. The tip of the seed bulb is cut in half, then watered until it is quite wet Planting is done in the afternoon.

4. Maintenance; covering watering, fertilizing, weeding and controlling pests and diseases.

5. Provision of fertilizer D I Grow; D.I.Grow fertilizers given are of two types, namely D.I.Grow Green and D.I.Grow Red. DIGrow Green is given at age 21,2 and 35 days after planting and DIGrow Red is given at age 42 and 4 days after planting in accordance with the concentration of tratment, namely DI Grow 0 ml.1-1 (G0), DIGrow 2, 5 ml.l-1 (G1), DI Grow 5.0 ml.1-1 (G2), DIGrow 7.5 ml.1-1 (G3).

Determination of the harvest stage is done after the plants are 60 days after planting with the characteristics of the plant are quite old, with almost $75-90 \%$ of the stem has been loosened and the leaves are yellowing, the bulbs appear dense and the skin color of the tuber is shiny or red. Harvesting is done by removing the plants and their leaves and trying to clean the soil attached to the tubers. 


\subsection{Research Instrument}

The research instruments will be carried out on variables, namely plant height, leaf number, tuber number per clump, fresh weight and oven dry tubers per clump, fresh and dry weight of stover oven and harvest index.

\subsection{Analysis Method}

Data from research results are analyzed statistically using diversity analysis to determine the effect of treatment on observed variables. Whereas, to find out the real difference between treatments used the LSD test with a level of 5\%. To find out the closeness of the relationship between variables observed correlation analysis was conduct.

\section{Result and Discussion}

From the results of statistical analysis of all observed variables and the results of the significance of the growth space $(\mathrm{J})$ and fertilizer concentration of D.I.Grow $(\mathrm{G})$ and their interactions $(\mathrm{JxG})$ on the observed variables are presented in Table 3.

Table 1. The significance of the effect of the growth room arrangement $(\mathrm{J})$ and the concentration of fertilizer D.I.Grow $(\mathrm{G})$ and their interaction $(\mathrm{JxG})$ on the observed variables.

\begin{tabular}{lccc} 
No $\quad$ Variable & \multicolumn{3}{c}{ Treatment } \\
\cline { 2 - 4 } & The growing & D.I.Grow fertilizer Interaction \\
& Space $(\mathrm{J})$ & $* *$ & $(\mathrm{G})$ \\
\hline 1. Maximum plant height $(\mathrm{cm})$ & $* *$ & $* *$ & $\mathrm{~ns}$ \\
2. Maximum number of regions (sheet) & $* *$ & $* *$ & $\mathrm{~ns}$ \\
3. Number of tubers per clump (tuber) & $*$ & $\mathrm{~ns}$ & $\mathrm{~ns}$ \\
4. Fresh weight of tubers per clump $(\mathrm{g})$ & $*$ & $\mathrm{~ns}$ & $\mathrm{~ns}$ \\
5. Oven dry weight of tuber per clum $(\mathrm{g})$ & $*$ & $*$ & $\mathrm{~ns}$ \\
6. Fresh weight of stover per clump $(\mathrm{g})$ & $*$ & $*$ & $\mathrm{~ns}$ \\
7. Dry weight of crusty oven per clump $(\mathrm{g})$ & $\mathrm{ns}$ & $\mathrm{ns}$ & $\mathrm{ns}$ \\
8. Harvest index $(\%)$ & & & \\
\hline
\end{tabular}

\footnotetext{
Description: $\mathrm{ns}=$ Not significant effect $(\mathrm{P} \geq 0.05)$

$*$ = Significant influence $(\mathrm{P}<0.05)$

$* *$ = Very significant effect $(\mathrm{P}<0.01)$
}

The interaction between the arrangement of growing space and the concentration of fertilizer D.I.Grow $(\mathrm{KxG})$ had no significant effect $(\mathrm{P} \geq 0.05)$ on all observed variables. Arrangement of growing space has a very significant effect $(\mathrm{P}<0.01)$ on maximum plant height, maximum number of leaves and number of tubers per clump; significant effect ( $\mathrm{P}$ $<0.05$ ) on fresh weight and oven dry weight of tubers per clump and fresh weight and dry weight of stover oven per clump and no significant effect ( $P$ nyata0.05) on the harvest index. The treatment of DI Grow $(\mathrm{G})$ fertilizer concentration significantly $(\mathrm{P}<0.05)$ on maximum plant height and fresh weight and dry weight of stover oven, had a very significant effect ( $P$ $<0.01$ ) on the maximum number of leaves and number of tubers per clump but no significant effect $(\mathrm{P}>0.05)$ on fresh weight and oven dry weight of tubers per clump and harvest index (Table 1) 
1. Maximum plant height $(\mathrm{cm})$

The highest maximum plant height was obtained at compost dose of 6 tons ha-1 (K2) $120.92 \mathrm{~cm}$ and the lowest was without compost (K0) of $109.42 \mathrm{~cm}$. Provision of NPK Phonska fertilizer tends to increase plant height.

2. Number of leaves $(\mathrm{cm})$

The highest average number of leaves was obtained at compost dosages of 0 tons ha- 1 (K0)10.33 different strands were not significant with other compost doses. The treatment of NPK Phonska $200 \mathrm{~kg}$ ha-1 (P1) gave the highest maximum number of leaves as much as 9.58 strands, which were not significantly different from other NPK Phonska treatments.

3. Number of leaves $(\mathrm{cm})$

The highest number of fruits per plant was obtained from the treatment of 8 tons ha- 1 (K3) compost ie 20.83 fruits and the lowest number of fruits per plant was obtained at 0 tons ha-1 (K0) 15.42 fruits. The dosage of NPK Phonska caused the number of fruits per plant to increase, the highest was obtained from the Phonska NPK treatment of $400 \mathrm{~kg} / \mathrm{ha}$ (P3), which was 19.58 different fruits were not significant with other treatments.

4. Fresh Weight of Fruit per plant (g)

The freshest weight of fruit per plant was obtained in the treatment of 8 tons ha-1 (K2) compost ie $380.42 \mathrm{~g}$ and the fresh weight of fruit per plant was obtained at 0 tonha- 1 (K0), which was $264.08 \mathrm{~g}$. The freshest weight of fruit per plant was obtained from NPK 400 kgha-1 (P3) treatment, which was

5. Fresh Weight of Stover (g)

The highest fresh stover weight was obtained in the treatment of 8 tons ha-1

compost, which was $360.92 \mathrm{~g}$ which was significantly different from the treatments. The highest fresh stover weight was obtained at NPK $200 \mathrm{~kg}$ ha-1 (P1) treatment which was $328.50 \mathrm{~g}$ which was different from the other treatments. $351.75 \mathrm{~g}$ which was not significantly different from other treatments.

6. Dry Weight of Fruit Oven per plant (g)

The highest dry fruit oven weight was obtained in the treatment of 8 tons ha-1 (K2) compost ie $30.58 \mathrm{~g}$ which was not significantly different from the other treatments, the lowest was obtained in the treatment of 0 tons ha- $1(\mathrm{~K} 0)$ which was $23.50 \mathrm{~g}$. The highest oven dry weight was obtained from NPK 400 kgha-1 (P3) treatment which was $29.17 \mathrm{~g}$ which was different from the other treatments.

7. Weight of Drying Stover Oven (g)

The highest dry weight of stover oven was obtained from the treatment of 8 tons ha-1 (K2) compost ie $53.17 \mathrm{~g}$. The highest dry weight of stover oven was obtained from NPK Phonska 200 kgha-1 (P1) treatment, which was $48.95 \mathrm{~g}$ which was different from the other treatments Interaction setting of growing space with a concentration of fertilizer D.I.Grow

The interaction of growing space regulation with D.I. Grow fertilizer concentration has no significant effect on all observed variables. The highest fresh weight and root dry weight of the clump tubers were obtained with a spatial growth pattern of $20 \mathrm{~cm} \times 20 \mathrm{~cm}$, weighing $44.17 \mathrm{~g}$ and $4.52 \mathrm{~g}$, increasing by $18.92 \%$. And $88.33 \%$ of the lowest efficiency of the spatial arrangement. $20 \mathrm{~cm} \times 10 \mathrm{~cm}$, namely $37.14 \mathrm{~g}$ and $2.40 \mathrm{~g}$. The high fresh weight and dry weight of tubers per clump were corroborated by the maximum height of the plant, the maximum number of leaves, the number of tubers per clod, the fresh weight of the stem and the dry weight of the kiln where the size average growth was $20 \mathrm{~cm}$ x $20 \mathrm{~cm}$. If you define a space of $20 \mathrm{~cm} \times 20 \mathrm{~cm}$, the influence on the growth and the yield of the shallot is significant. 
This is seen from the maximum height of the plant $(44.27 \mathrm{~cm})$, the maximum number of leaves (26.73 strands) where the increasing number of leaves will increase. process of photosynthesis and produce photosynthesis which will then be transferred to the tuber. Tuber tubing enlargement is due to more dominant cellular hypertrophy than cell division. The increase in the fresh weight of the tuber is influenced by the absorption of water and the accumulation of photosynthesis translocate the leaves to the tuber. Thus, the difference in water content will affect the fresh weight of the tubers produced [9].

The plant of growth sums will affect plant yield as indicated by the number of tubers ( 8.15 seeds), fresh berarasan $(10.41 \mathrm{~g})$ and bread oven $(258 \mathrm{~g})$. The number of tubers by tertiary formation was obtained in the rumbar arrangement growing by $20 \mathrm{~cm} \times 20 \mathrm{~cm}$, which was 8.15 seeds or increased by $32.09 \%$ compared to the arrangement of the space to grow 20 $\mathrm{cm} \times 10 \mathrm{~cm}$. Hall above his soul. The low fresh weight and oven dry weight of tubers per clump in the spatial arrangement grows $20 \mathrm{~cm} \times 10 \mathrm{~cm}$; due to overgrowth of growing dense rags that are closely related to plant populations per unit area, and competition between plants in the use of light, water, nutrients, and space, so that it can affect growth and tuber yield. The narrower the growing space, the light received by plants decreases due to competition between plants in getting sunlight, so that the effect on photosynthesis decreases and growth and yields are also lower.

The increasing concentration of IN Grow fertilizer causes an increase in the growth variable and yield of shallots. The highest number of tubers per clump was obtained at the D I Grow fertilizer concentration of 7.5 ml.1-1 which was 8.11 tubers which increased by $22.87 \%$ which was significantly different from the DI Grow fertilizer concentration of $5.0 \mathrm{ml} .1-1$ which was 8.02 the tuber increased by $21.52 \%$ compared to the concentration of D I Grow 0 ml.1-1 which was 6.60 bulbs. The high number of tubers per clump is followed by the maximum plant height and maximum number of leaves. This is due to the availability of nutrients $(\mathrm{N}, \mathrm{P}, \mathrm{K})$ found in fertilizer D.I. Grow supports nutrients in the soil. From the results of soil analysis showed that the availability of potassium nutrients in the soil is very low so that the addition of potassium nutrients through fertilizer D.I.Grow in plants will affect the number of tubers to increase. Potassium nutrients have a very important role in the placement and storage of assimilates, increasing the number of tubers [10].

The highest fresh weight and oven dry weight of tubers per clump were obtained in the treatment of D I Grow fertilizer $7.5 \mathrm{ml} .1-1$ of $42.78 \mathrm{~g}$ and $4.37 \mathrm{~g}$ increased by $9.02 \%$ and $47.13 \%$ compared to D I Grow treatment $0 \mathrm{ml} .1-1$ is $39.24 \mathrm{~g}$ and $2.97 \mathrm{~g}$ although it is not significantly different. The high oven dry weight of tubers per clump was followed by the maximum plant height, maximum number of leaves, number of tubers per clump, fresh weight and dry weight of stover oven. This is due to the higher concentration of fertilizer D.I.Grow, the amount of nutrients available will meet the needs of plants so that it will produce high dry weight of plants. To carry out photosynthesis plants need nutrients, the more nutrients are absorbed, the greater the accumulative photosynthesis from photosynthesis, the greater the fresh weight of the plant. The dry weight of plants is a balance between taking carbon dioxide (photosynthesis) and expenditure (respiration), if respiration is greater than photosynthesis, the plant will reduce its dry weight and vice versa [7]. The dry weight of plants reflects the nutritional status of plants and plant dry weight is an indicator that determines whether or not a plant is very closely related to nutrient availability and absorption [8]. 


\section{Conclusion and Recommendations}

\subsection{Conclusion}

1. The interaction of the regulation of growing space with the concentration of fertilizer D.I.Grow has no significant effect on all observed variables.

2. The highest fresh weight of oven dry weight of tubers per clump was obtained in the spatial arrangement of growth of $20 \mathrm{~cm} \mathrm{x} 20 \mathrm{~cm}$, weighing $44.17 \mathrm{~g}$ and $4.52 \mathrm{~g}$, increasing by $18.92 \%$ and $88.33 \%$ compared to the lowest yield in spatial arrangement grew $20 \mathrm{~cm}$ x $10 \mathrm{~cm}$, namely $37.14 \mathrm{~g}$ and $2.40 \mathrm{~g}$.

3. Increasing the concentration of fertilizer in Grow which increases, increasing the growth variable and yield of shallots. The highest number of tubers per clump was obtained at the DIGrow fertilizer concentration of $7.5 \mathrm{ml} .1-1$ which was 8.11 tubers which increased by $22.87 \%$ which was significantly different from the D I Grow fertilizer concentration of $5.0 \mathrm{ml} .1-1$ which was 8.02 the tuber increased by $21.52 \%$ compared to the concentration of DIGrow 0 ml.1-1 which was 6.60 bulbs.

\subsection{Suggestion}

1. Arrangement of space grows $20 \mathrm{~cm} \times 20 \mathrm{~cm}$ and the concentration of fertilizer in I D Grow $7.5 \mathrm{ml} .1-1$ can be used to increase the growth and yield of shallots.

2. Further research needs to be done with a combination of more varied treatments in other places with different land conditions than the previous experiment site.

\section{References}

[1] Rukmana, R.: Bawang merah budidaya dan pengolahan pasca panen. Kanisius, Yogyakarta (1995)

[2] Wibowo, S.: Budidaya Bawang Merah. Penebar Swadaya, Jakarta (1999)

[3] Deptan.: Pengenalan Dan Pengendalian Beberapa OPT Benih Hortikultura (2007)

[4] Rahayu., Estu., \& Berlian., Nur.: Bawang merah. Penebar Swadaya, Jakarta (2004)

[5] Badan Pusat Statistik dan Direktorat Jendral.: Produksi Bawang Merah Menurut Provinsi Tahun 2009-2013. Kementrian Pertanian Republik Indonesia (2014)

[6] Dinas Pertanian.: Berita lengkap, Provinsi Bali (2015)

[7] Gardner, F.P., Pearce, R.B., and Mitchell, R.L.: Physiology of Crop Plants (Fisiologi Tanaman Budidaya. Terjemahan: H. Susilo). Penerbit Universitas Indonesia Press, Jakarta (1991)

[8] Prawiratna, W.S., \& Tjondronegoro, P.: Dasar-Dasar Fisiologi Tanaman Jilid II. PT Gramedia Pustaka Utama, Jakarta (1995)

[9] Setiyowati, S.H., \& R.B.Hastuti.: Pengaruh perbedaan konsentrasi pupuk organik cair tehadap produksi bawang merah (Allium ascalonicum L.) laboratorium biologi dan struktur fungsitumbuhan fmipa undip. BIOMA. Vol. 12. pp. 44-48 (2010)

[10] Sumarni, N., Rosliani R., Basuki. R. S., \& Hilman Y.: Pengaruh Varietas Tanah, Status K-Tanah Dan Dosis Pupuk Kalium Terhadap Pertumbuhan Hasil Umbi, Dan Serapan Hara K Tanaman Bawang Merah. Pusat Penelitian Dan Pengembangan Hortikultura, J-hort. Vol. 22(3). pp. 233-241 (2012) 